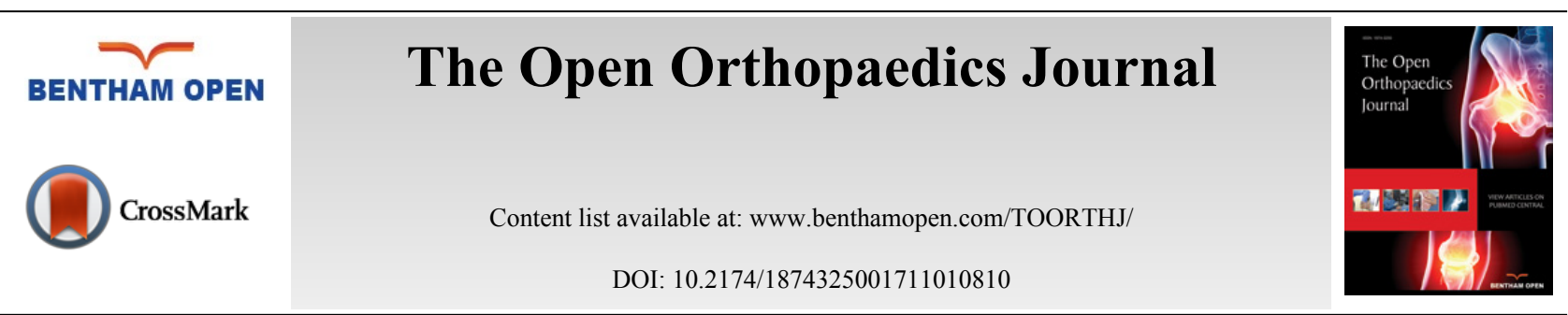

EDITORIAL

\title{
Shoulder Instability. Current Concepts and Controversies
}

Shoulder instability is a highly prevalent problem that affects mainly young and able individuals. As such, its impact in the quality of life of the general population is significant. Its evaluation and management have traditionally been controversial: the pathoanatomy, the clinical [1] and radiologic [2] evaluation and the choice of an adequate treatment, even before the advent of arthroscopic surgery [3], are heavily disputed topics. Most of the different approaches to the problem, from defining what is the best conservative treatment after a first episode [4] to selecting the most appropriate surgical technique, are disputed between orthopedic surgeons and constantly under review [5]. Notwithstanding that, in the last few years, a lot of very valuable information has been published that is relevant to the topic.

The purpose of the current thematic issue is to focus on both well-stablished knowledge and controversial issues. To do that, there will be a mixture of traditional revision papers that summarize current knowledge and "Controversies" reviews in which the authors will present conflicting literature evidence in a light that is worthwhile for the reader.

The first part includes three reviews that focus in general topics like anatomy [6], evaluation [7] and imaging [8] of the unstable shoulder. All these are well-trodden topics but there are constant innovations in all three fields so a review should be welcomed.

The second part is focused in anterior instability with four reviews of the natural history [9], management alternatives of bone defects $[10,11]$ and soft tissues [12] in instability and a fifth over the failed shoulder instability patient [13]. Three "controversies" papers focus in specially disputed topics: management of the first shoulder dislocation [14], open or arthroscopic procedures [15] and associated procedures during Bankart repair [16].

The third part of the issue will focus in multidirectional and posterior instability dealing with a general outline of the diagnosis and treatment in four reviews [17 - 20].

Finally the issue closes with two separate papers focusing in rehabilitation strategies in shoulder instability [21] and anesthetic management [22] of these patients.

The editors hope that this monographic issue will allow the advanced reader in clarifying what does the most current evidence on shoulder instability controversies. It should also be a good reference guide to review the basics of shoulder instability.

\section{REFERENCES}

[1] Munro W, Healy R. The validity and accuracy of clinical tests used to detect labral pathology of the shoulder--a systematic review. Man Ther 2009; 14(2): 119-30.

[http://dx.doi.org/10.1016/j.math.2008.08.008] [PMID: 18996735]

[2] Walz DM, Burge AJ, Steinbach L. Imaging of shoulder instability. Semin Musculoskelet Radiol 2015; 19(3): 254-68. [http://dx.doi.org/10.1055/s-0035-1549319] [PMID: 26021586]

[3] Chalmers PN, et al. Do Arthroscopic and Open Stabilization Techniques Restore Equivalent Stability to the Shoulder in the Setting of Anterior Glenohumeral Instability? A Systematic Review of Overlapping Meta-analyses. Arthroscopy 2014. [PMID: 25217207]

[4] Longo UG, Loppini M, Rizzello G, Ciuffreda M, Maffulli N, Denaro V. Management of primary acute anterior shoulder dislocation: Systematic review and quantitative synthesis of the literature. Arthroscopy 2014; 30(4): 506-22. [http://dx.doi.org/10.1016/j.arthro.2014.01.003] [PMID: 24680311]

[5] Bak K, Wiesler ER, Poehling GG. Consensus statement on shoulder instability. Arthroscopy 2010; 26(2): 249-55. 
[http://dx.doi.org/10.1016/j.arthro.2009.06.022] [PMID: 20141988]

[6] Cuéllar R, Ruiz Ibán MA, Cuéllar A. Anatomy and Biomechanics of the Unstable Shoulder. Open Orthop J $2017 ; 11$

[7] Valencia Mora M, Ruiz Ibán MA, Diaz Heredia J, et al. Physical Exam and Evaluation of the Unstable Shoulder. Open Orthop J 2017; 11

[8] Baudi P, Rebuzzi M, Matino G, Catani F. Imaging of the Unstable Shoulder. Open Orthop J 2017 ; 11

[9] Carpinteiro EP, Barros AA. Natural History of Anterior Shoulder Instability. Open Orthop J 2017; 11

[10] Valencia Mora MV, Ruiz Ibán MA, Diaz Heredia J, Ruiz Diaz R, Cuéllar R. Management of Humeral Defects in Anterior Shoulder Instability. Open Orthop J 2017; 11

[11] Harmsen K, Huijsmans PE. Management of Glenoid Defects in Anterior Shoulder Instability: A Review of Current Concepts. Open Orthop J $2017 ; 11$

[12] Brown M, Wallace A, Lachlan A, Susan A. Arthroscopic Soft Tissue Procedures for Anterior Shoulder Instability. Open Orthop J 2017; 11

[13] Cartucho A, Moura N, Sarmento M. Evaluation and Management of Failed Shoulder Instability Surgery. Open Orthop J 2017; 11

[14] Avila Lafuente JL, Moros Marco S, García Pequerul JM. Controversies in the Management of the First Time Shoulder Dislocation. Open Orthop J 2017; 11

[15] Huerta A, Rincón G, Peidro L, Combalia A, Sastre S. Controversies in the Surgical Management of Shoulder Instability: Open vs Arthroscopic Procedures. Open Orthop J 2017; 11

[16] Moros Marco SM, Avila Lafuente JL, Ruiz Ibán MA, Diaz Heredia J. Controversies In The Surgical Management Of Shoulder Instability: Associated Soft Tissue Procedures. Open Orthop J 2017; 11

[17] Diaz Heredia J, Ruiz Iban MA, Riuz Diaz R, Moros Marco S, Gutierrez JC, Valencia Mora M. The Posterior Unstable Shoulder: Natural History, Clinical Evaluation and Imaging. Open Orthop J 2017; 11

[18] Ruiz Iban MA, Diaz Heredia J, García Navlet M, Serrano F, Oliete MS. Multidirectional Shoulder Instability: Treatment. Open Orthop J 2017; 11

[19] Garcia Navlet M, Asenjo-Gismero VC. Multidirectional Instability: Natural History and Evaluation. Open Orthop J 2017; 11

[20] Sanchez Alepuz E, Pérez-Barquero JA, Jorge NJ, García FL, Baixauli VC. Treatment of The Posterior Unstable Shoulder. Open Orthop J $2017 ; 11$

[21] Alexander S. Rehabilitation for Shoulder Instability-Current Approaches. Open Orthop J 2017; 11

[22] Acebedo Bambaren I, Dominguez F, Elias Martin E, et al. Anesthesia and Analgesia in the Patient with an Unstable Shoulder. Open Orthop J $2017 ; 11$

\author{
Miguel Angel Ruiz Ibán \\ Hospital Universitario Ramon y Cajal \\ Cta Colmenar km9 \\ 100, Madrid \\ 28046, Spain \\ E-mail: drmri@hotmail.com
}

\title{
C) 2017 Miguel Angel Ruiz Ibán.
}

This is an open access article distributed under the terms of the Creative Commons Attribution 4.0 International Public License (CC-BY 4.0), a copy of which is available at: https://creativecommons.org/licenses/by/4.0/legalcode. This license permits unrestricted use, distribution, and reproduction in any medium, provided the original author and source are credited. 